\title{
GeoChip 4: a functional gene-array-based high-throughput environmental technology for microbial community analysis
}

\author{
QICHAO TU, ${ }^{* 1}$ HAO YU,${ }^{*}+{ }^{1}{ }^{1}$ ZHILI HE, ${ }^{*}$ YE DENG,${ }^{*}$ LIYOU WU,${ }^{*}$ JOY D. VAN NOSTRAND, ${ }^{*}$ \\ AIFEN ZHOU, ${ }^{*}$ JAMES VOORDECKERS, ${ }^{*}$ YONG-JIN LEE, ${ }^{*}$ YUJIA QIN, ${ }^{*}$ CHRISTOPHER L. HEMME, \\ ZHOU SHI, * KAI XUE, * TONG YUAN,* AIJIE WANG§ and JIZHONG ZHOU* ${ }^{* *}$ \\ *Department of Microbiology and Plant Biology, Institute for Environmental Genomics (IEG), University of Oklahoma, Norman, \\ OK 73019, USA, †State Key Laboratory of Urban Water Resource and Environment, Harbin Institute of Technology, Harbin \\ 150090, China, $\$$ School of Environmental Science and Engineering, Liaoning Technical University, Fuxin, Liaoning 123000, \\ China, §Research Center for Eco-Environmental Sciences, Chinese Academy of Sciences, Beijing 100085, China, IIState Key Joint \\ Laboratory of Environment Simulation and Pollution Control, School of Environment, Tsinghua University, Beijing 100084, \\ China, ${ }^{* *}$ Earth Science Division, Lawrence Berkeley National Laboratory, Berkeley, CA 94720, USA
}

\begin{abstract}
Micro-organisms play critical roles in many important biogeochemical processes in the Earth's biosphere. However, understanding and characterizing the functional capacity of microbial communities are still difficult due to the extremely diverse and often uncultivable nature of most micro-organisms. In this study, we developed a new functional gene array, GeoChip 4, for analysing the functional diversity, composition, structure, metabolic potential/activity and dynamics of microbial communities. GeoChip 4 contained approximately 82000 probes covering 141995 coding sequences from 410 functional gene families related to microbial carbon (C), nitrogen (N), sulphur (S), and phosphorus (P) cycling, energy metabolism, antibiotic resistance, metal resistance/reduction, organic remediation, stress responses, bacteriophage and virulence. A total of 173 archaeal, 4138 bacterial, 404 eukaryotic and 252 viral strains were targeted, providing the ability to analyse targeted functional gene families of micro-organisms included in all four domains. Experimental assessment using different amounts of DNA suggested that as little as 500 ng environmental DNA was required for good hybridization, and the signal intensities detected were well correlated with the DNA amount used. GeoChip 4 was then applied to study the effect of long-term warming on soil microbial communities at a Central Oklahoma site, with results indicating that microbial communities respond to long-term warming by enriching carbon degradation, nutrient cycling (nitrogen and phosphorous) and stress response gene families. To the best of our knowledge, GeoChip 4 is the most comprehensive functional gene array for microbial community analysis.
\end{abstract}

Keywords: environmental technology, functional gene array, GeoChip 4, microbial community analysis

Received 10 November 2013; revision received 2 February 2014; accepted 5 February 2014

\section{Introduction}

Micro-organisms, which encompass a diverse number of life forms in the Earth's biosphere, play integral and unique roles in ecosystems, such as bio-geochemical cycling of carbon (C) (Bardgett et al. 2008), nitrogen (N) (Gruber \& Galloway 2008), sulphur (S), phosphorous (P) and various metals. Understanding the diversity, composition, structure, function and interactions of microbial communities over time and space is crucial in microbial ecology. However, it is still very difficult to

Correspondence: Jizhong Zhou, Fax: 405325 7552; E-mail: jzhou@ou.edu

${ }^{1}$ These two authors contributed equally to this work. detect, identify, characterize and quantify the functional capacity of microbial communities due to the extremely diverse and uncultivated nature of most micro-organisms. It is estimated that a total of $1.2 \times 10^{29}$ bacterial cells are present in the open ocean (Whitman et al. 1998), $2.9 \times 10^{29}$ in the subseafloor sediment (Kallmeyer et al. 2012) and $2.6 \times 10^{29}$ in soil (Whitman et al. 1998). Different approaches suggest that the number of bacterial species in a gram of soil varies between 2000 and 8.3 million (Gans et al. 2005; Schloss \& Handelsman 2006; Roesch et al. 2007), and the majority of these $(>99 \%)$ are as-yet-uncultivated (Rappe \& Giovannoni 2003). Characterizing such vast diversity and understanding the mechanisms of community assembly are very difficult. Therefore, it is highly desirable to develop 
high-throughput metagenomic technologies for microbial community analysis.

Indeed, several high-throughput technologies have recently been developed and applied to microbial community analysis, including next-generation sequencing (Sogin et al. 2006; Mardis 2008; Shendure \& Ji 2008; Ansorge 2009; MacLean et al. 2009; Metzker 2010), single cell genomics (Lasken 2007; Walker \& Parkhill 2008; Woyke et al. 2010; Huang \& Zhou 2012), microbial ecological microarrays such as PhyloChip (Brodie et al. 2006, 2007; Schatz et al. 2010) and functional gene arrays (FGAs), for example, GeoChip (He et al. 2007, 2010a, 2012a). Nextgeneration sequencing technology using the Roche 454 and Illumina platforms has been applied to capture sequences for both targeted genes with available primers (e.g., 16S rDNA, amoA and nifH) and metagenomes (Sogin et al. 2006; He et al. 2010b; Qin et al. 2010, 2012; Hess et al. 2011; Mackelprang et al. 2011; Brisson et al. 2012; Deng et al. 2012; Díez et al. 2012; Sintes et al. 2013; Yatsunenko et al. 2012; Zhou et al. 2012). These data have provided many novel insights into the phylogenetic/taxonomic, genetic, and functional diversity, structure and composition of microbial communities from different environments. Microarrays such as PhyloChip and GeoChip have also been applied to profile the phylogenetic and functional structure and composition of known microbial populations (Brodie et al. 2007; Zhou et al. 2008, 2012; Wang et al. 2009; Hazen et al. 2010; He et al. 2010b), giving novel insights into how environmental factors affect microbial communities in various habitats.

GeoChip is a comprehensive functional gene array targeting hundreds to thousands of different gene families that play important roles in various biogeochemical processes, enabling researchers to comprehensively analyse the functional diversity, composition and structure of microbial communities in various environments. During the past decade, several versions of GeoChip-like FGAs have been developed and were proven to be effective high-throughput tools for microbial community analysis (Wu et al. 2001; Rhee et al. 2004; He et al. 2007, 2010a). GeoChip 2.0 contained more than 24000 probes and covered more than 10000 gene sequences from 150 gene families in key microbial-mediated biogeochemical processes $(\mathrm{He}$ et al. 2007), while GeoChip 3.0 contained about 28000 probes and covered approximately 57000 gene sequences from 292 gene families in various functional processes (He et al. 2010a). These two previous versions of GeoChip have been used to analyse microbial communities associated with various environments (He et al. 2012a,b), including soil habitats (Zhou et al. 2008, 2012; He et al. 2010b; Trivedi et al. 2012; Yergeau et al. 2012), aquatic ecosystems (Taş et al. 2009; Kimes et al. 2010), extreme environments (Wang et al. 2009;
Mason et al. 2010), contaminated sites (Leigh et al. 2007; Liang et al. 2009, 2011; Liebich et al. 2009; Van Nostrand et al. 2009; Xiong et al. 2010; Xu et al. 2010) and bioreactors (Liu et al. 2010, 2012; Zhou et al. 2013). All of these studies have indicated that GeoChip is a powerful FGA-based technology to survey the functional diversity, composition, structure, metabolic potential/activity and dynamics of microbial communities, and link them with ecosystem processes and functions.

The objective of this study was to develop a more comprehensive functional gene array, GeoChip 4, for broader applications in analysing biogeochemical processes and microbial responses to environmental perturbations. In addition to updating conventional gene families involved in carbon, nitrogen, sulphur, phosphorous cycles, organic remediation, metal reduction and antibiotics, we also added many previously untargeted gene families, such as those involved in various environmental stress responses, bacteriophages and virulence processes. After the establishment of experimental and data analysis procedures, the developed GeoChip 4 was used to analyse the responses of soil microbial communities to long-term warming at a Central Oklahoma site.

\section{Materials and methods}

\section{Sequence retrieval and probe designing}

GeoChip 4 employed a similar pipeline (Fig. S1, Supporting information) that was used for GeoChip 3.0 (He et al. 2010a). Sequences from gene families covered in previous GeoChip versions were updated using existing keyword queries. For gene families involved in microbial stress responses, bacteriophages and virulence, keywords describing the gene families were created and searched against the NCBI nr database. Candidate protein sequences were fetched and searched against prebuilt HMM models by HMMER (Eddy 1998) for verification. Corresponding nucleotide sequences were retrieved and used for probe design by CommOligo 2.0 (Li et al. 2005). Candidate probes were searched against NCBI nt/env_nt databases for specificity.

\section{Microarray construction}

GeoChip 4 uses the Roche NimbleGen (Madison, WI, USA) $12 \times 135 \mathrm{~K}$ (12 arrays on one slide with $135 \mathrm{~K}$ probes for each array) platform because of its high density and capacity. The microarray template was obtained from NimbleGen. Probes were placed in every other position across the array so that each probe was adjacent to four void spots (Fig. S2, Supporting information). All GeoChip 4 probes were randomly placed at available 
positions except for the $16 \mathrm{~S}$ probes, which were placed in specific positions throughout the array as positive hybridization controls. Three copies of 563 negative control probes targeting seven thermophile strains were randomly placed on the array. Six thousand 50-mer common oligonucleotide reference standard (CORS) features (with the same probe sequence) were also randomly positioned for data normalization and comparison (Liang et al. 2010). Microarrays were synthesized and manufactured by Roche NimbleGen.

\section{DNA extraction, purification and quantification}

Soil DNA taken from the BioCON experimental site (Reich et al. 2001) and a long-term OK warming site (Luo et al. 2001) was extracted by freeze-grinding mechanical lysis (Zhou et al. 1996) and purified using a low-melting agarose gel followed by phenol extraction. Community DNA extracted from BioCON soil sample was used for experimental evaluation of GeoChip 4, and DNA from the OK warming site was used in the application study. DNA quality was assessed by the ratios of A260/A280 and A260/A230 using a NanoDrop ND-1000 spectrophotometer (NanoDrop Technologies Inc., Wilmington, DE), and final DNA concentrations were quantified with PicoGreen (Ahn et al. 1996) using a FLUOstar Optima microplate reader (BMG Labtech, Jena, Germany).

\section{Target labelling and hybridization}

The purified DNA was labelled with Cy-3 using random primers and the Klenow fragment of DNA polymerase I (Wu et al. 2006). Labelled DNA was purified using the QIA quick purification kit (Qiagen, Valencia, CA, USA) according to the manufacturer's instructions, measured on a NanoDrop ND-1000 spectrophotometer and then dried down in a SpeedVac (ThermoSavant, Milford, MA, USA) at $45^{\circ} \mathrm{C}$ for $45 \mathrm{~min}$. Dried DNA was rehydrated with $2.68 \mu \mathrm{L}$ sample tracking control (NimbleGen) to confirm sample identity. The samples were incubated at $50{ }^{\circ} \mathrm{C}$ for $5 \mathrm{~min}$, vortexed for $30 \mathrm{~s}$ and then centrifuged to collect all liquid at the bottom of the tube. Hybridization buffer $(7.32 \mu \mathrm{L})$, containing $40 \%$ formamide, $25 \%$ SSC, $1 \%$ SDS, $2.38 \%$ Cy3-labelled alignment oligo (NimbleGen) and 2.8\% Cy5-labelled CORS target, was added. The samples were then mixed by vortexing, spun down, incubated at $95{ }^{\circ} \mathrm{C}$ for $5 \mathrm{~min}$ and maintained at $42{ }^{\circ} \mathrm{C}$ until hybridization. An HX12 mixer (NimbleGen) was placed onto the array using NimbleGen's precision mixer alignment tool, and then, the array was preheated to $42{ }^{\circ} \mathrm{C}$ on a hybridization station (MAUI, BioMicro Systems, Salt Lake City, UT, USA) for at least $5 \mathrm{~min}$. Samples $(6.8 \mu \mathrm{L})$ were then loaded onto the array surface and hybridized approximately $16 \mathrm{~h}$ with mixing.

\section{Imaging, data preprocessing and analysis}

After hybridization, arrays were scanned at full laser power and $100 \%$ photomultiplier tubes gain with a NimbleGen MS 200 Microarray Scanner (Roche NimbleGen). Scanned images were gridded by NimbleScan software using the gridding file containing GeoChip 4 probes and NimbleGen control probes to obtain the signal intensity for each probe. Probe spots with coefficient of variance $(\mathrm{CV})>0.8$ were removed.

In general, a local background that represents the actual background signal for each spot is preferred for signal-to-noise ratio (SNR) calculations and false-positive filtering instead of the global background generated by NimbleScan; so a different method for background calculation was introduced here. To obtain a local background signal for each probe, a customized void gridding file targeting positions without probes was generated. The scanned images were gridded using the void gridding files. The local background signal for each probe was calculated as the mean signal intensity of the four neighbouring void spots. When all of the four neighbouring void spots were not valid, the set of eight void spots surrounding its closest neighbours was used (Fig. S2, Supporting information). A probe was discarded if all twelve void spots failed to meet the $\mathrm{CV}$ criteria $(\mathrm{CV}<0.8)$. Signal standard deviation for the background was calculated as:

$$
\text { MeanVoidStdev }=\sqrt{\frac{\operatorname{stdev}_{1}^{2}+\operatorname{stdev}_{2}^{2}+\ldots+\operatorname{stdev}_{n}^{2}}{n}}
$$

where $\operatorname{stdev}_{i}$ is the standard deviation for each void spot, and $n(\leq 8)$ is the number of void spots. SNR was calculated as previously described (He \& Zhou 2008). Signal intensities for each probe were normalized by the mean signals from all spiked CORS probes.

\section{Statistical analysis}

Various statistical methods were used for further analysis. Three different nonparametric multivariate analysis methods, adonis (permutational multivariate analysis of variance using distance matrices), anosim (analysis of similarities) and MRPP (multiresponse permutation procedure), as well as detrended correspondence analysis (DCA), were used to measure the overall differences of community functional gene structure between treatment and control samples (Zhou et al. 2012). The significance of differences in relative abundance of functional genes between control and treatment samples was evaluated using Student's t-test. 


\section{Results}

\section{Gene families included in GeoChip 4}

In addition to updating those gene families already covered by previous GeoChips, GeoChip 4 gene coverage was expanded by adding 98 new gene families to target more microbially mediated functional processes involved in microbial stress response (45 gene families) and virulence (13) as well as genes for environmentally related bacteriophages (40). Gene families included in previous versions of GeoChip were also included on GeoChip 4, and coverage of these gene families was manually checked and improved by modifying keyword queries for some genes and increasing gene sequence coverage from the latest public database at the time of development (continuous update since June 2010). Specifically, 312 gene families were included to target functional processes such as antibiotic resistance (11), carbon cycling (41), energy processing (4), metal resistance (44), nitrogen cycling (17), organic remediation (184), phosphorus utilization (3), sulphur (6), bch Y and gyr $B$ genes. A detailed description of these gene families and functional processes is in (He et al. 2010a). Newly targeted gene families in GeoChip 4 are described below:

Stress responses. Micro-organisms are sensitive to environmental conditions, and many abiotic and/or biotic environmental fluctuations, such as temperature, $\mathrm{pH}$, oxygen, and nutrition, could affect their growth, functions, dynamics and evolution. To survive in such environmental variability, micro-organisms have developed different mechanisms for temporary and/or long-term adaptation. To study microbial responses to various environmental stressors, 45 gene families involved in stress responses were selected. (i) Sigma factors, general stress responses and stringent responses. Different genes are activated under different environmental conditions to regulate microbial responses. Four sigma factor genes $\left(\sigma^{70}, \sigma^{38}, \sigma^{32}\right.$ and $\left.\sigma^{24}\right)$, one general stress response gene (katE) and one stringent response gene (obgE) were selected. (ii) Temperature. Functional genes targeting heat shock (dnaK, grpE, groES, and groEL) and cold shock ( $\operatorname{csp} A$ and $\operatorname{csp} B$ ) were selected. Regulatory genes, including $h r c A$ for heat shock and two-component genes desK$\operatorname{des} R$ for cold shock, were also selected. (iii) Osmolarity. Changes in extracellular osmotic pressure may elicit rapid water fluxes along the osmotic gradient to maintain the proper turgor for normal cellular physiology. Cells respond to osmotic shock by adjusting the cellular concentration of osmolytes or compatible solutes (Kempf \& Bremer 1998). Here, four functional genes involved in microbial osmotic stress response were selected, including opuE, proX, proV and proW. (iv) Oxidative stress and oxygen limitation. Three functional genes ( $\operatorname{ahpC}, \operatorname{ahpF}$ and $k a t A)$ and two regulatory genes (perR and $\operatorname{oxy} R$ ) were selected for oxidative stress response. The expression of ahpCF and kat are controlled by transcriptional factor oxyR or perR (Pomposiello \& Demple 2001; Fuangthong et al. 2002). For oxygen limitation, two cytochrome genes ( $c y d A$ and $c y d B$ ), three nitrate reductase genes (narH, narI and narJ), one regulatory gene (fnr) and a two-component system gene $(\operatorname{arc} A-\operatorname{arcB})$ were selected. (v) Nutrient limitation. Limited nutrients such as glucose, phosphate and nitrogen are common stresses for micro-organisms in the natural environment. Glucose is the preferred carbon and energy source for most micro-organisms, and two genes ( $b g l P$ and $b g l H)$ were selected for glucose limitation. Phosphate is the essential nutrient for microbial metabolism for its role in many functional structures such as nucleic acid, ribosomes and membranes, and phosphate-specific transport system genes (pstS, pst $A, p s t B$ and $p s t C$ ), alkaline phosphate gene pho $A$ and the two-component system gene phoB were selected for phosphate limitation. Nitrogen is also a key nutrient for micro-organisms, and glutamine synthase gene $g \ln A$ and regulatory genes $\operatorname{tn} r A$ and $g \ln R$ for nitrogen limitation were selected. (vi) Protein stress. Overexpression of recombinant proteins stimulates protein stress (Goff \& Goldberg 1985; Dong et al. 1995), and two genes (ctsR and $c l p C$ ) were selected.

Virulence. Bacteria are the most dominant group of pathogens and account for approximately $40 \%$ of all pathogens followed by fungi, helminthes, viruses and prions and protozoa (Taylor et al. 2001; Woolhouse \& Gowtage-Sequeria 2005). For pathogenicity, a pathogen must enter and cause damage to the host while evading the host defence mechanisms. Such pathogenicity is determined by multiple virulence factors such as adherence, colonization, invasion, secretion system, immune evasion, toxin production and iron uptake (Finlay \& Falkow 1997; Wu et al. 2008). Thus, these virulence factors could serve as specific markers for the detection and monitoring of a variety of pathogens in clinical and environmental samples. Here, 13 bacterial virulence factors, including adhesion, aerobactin, capsule, colonization factor, fimbriae, haemolysin, invasion proteins, siderophore, pilin, type III secretion proteins, sortase, toxin and virulence proteins, were selected. Adhesins are cell surface components or appendages of bacteria that facilitate bacterial colonization within their host (Kline et al. 2009). Siderophores, including aerobactin, are small, high-affinity iron-chelating compounds generally produced under iron-limiting conditions to scavenge iron (Bossier et al. 1988; Neilands 1995). The bacterial capsule promotes virulence by reducing host immune responses (Singh et al. 2011). 
Colonization factors are surface structures that allow bacteria to bind and colonize onto host cells (Tobias \& Svennerholm 2012). Toxins and haemolysins play an important role in toxigenesis by affecting and damaging a host cell directly and aggressively. Pilin is the major subunit protein of pili in many bacteria (Craig et al. 2003) and plays roles in surface attachment and DNA transfer by conjugation (Yang \& Bourne 2009; Carter et al. 2010). Sortases are a family of enzymes found in Gram-positive bacteria and act as both proteases and transpeptidases, which are required for cell wall anchoring protein production, adhesion to epithelial cells and colonization of the mouse intestine (Cossart \& Jonquières 2000; Mazmanian et al. 2001). The type III secretion system is particularly prevalent among Gram-negative bacterial pathogens to transport effectors directly into their hosts cells (Galan \& Collmer 1999).

Bacteriophages. Bacteriophages are potentially the most numerous form of life in Earth's biosphere (Grath \& Sinderen 2007), surpassing the number of bacteria by an order of magnitude (Bergh et al. 1989; Wommack \& Colwell 2000). In sea water, up to $9 \times 10^{8}$ virions per millilitre have been found in surface microbial mats (Wommack \& Colwell 2000), and more than $70 \%$ of marine bacteria might be infected by phages (Prescott 1993). It is expected that the number of virus in each gram of soil is $\sim 1.5 \times 10^{8}$, accounting for about $4 \%$ of the total bacterial population (Ashelford et al. 2003). Bacteriophages play several important roles in the environment, such as turnover of nutrients by lysis of their prokaryotic hosts (Weinbauer 2004), supplying released nutrients to other organisms (Suttle 1994, 2007) and driving evolution by transferring genetic information between multiple hosts (Chen \& Novick 2009; Gomez \& Buckling 2011).

To monitor the composition and abundance/activity of bacteriophages in the environment over time and space, we designed probes for 40 genes that are related to structure, host recognition, lysis and replication processes in phages. (i) Host recognition. The first critical step in any virus' life cycle is the recognition of its host organism through cell surface components such as receptors or lipopolysaccharides. Two long-tail fibre proteins, p38 and p37, responsible for bacterial host receptor recognition in T7 type phages, T2 (Riede et al. 1987) and T4 (Thomassen et al. 2003), respectively, were selected. (ii) Replication. Bacteriophages have a number of diverse replication mechanisms that have been reviewed extensively elsewhere (Weigel \& Seitz 2006). Some phages encode for all of the genes necessary for the replication of their genomes while others use components from their host's replication mechanism. Here, 25 genes encoded by bacteriophages for replication were selected, among which eight are encoded by $\mathrm{T} 4$ bacteriophage and the rest are common to multiple bacteriophages. (iii) Structure. Proteins representing major structural components of the virion were chosen with priority given to those that have previously been used as environmental markers to assess viral populations. Six genes encoding proteins that function in forming unique bacteriophage structures were selected, including contractile tail tube protein, contractile sheath protein, noncontractile tail protein, capsid protein, scaffolding protein and tape measure protein. (iv) Lysis. With the exception of the ssDNA Inoviridae (Hoffmann-Berling \& Mazé 1964), the end of the phage life cycle in bacteria involves the lysis and death of the host cell. Several different types of proteins and enzymes can be involved in this process and have been reviewed previously (Young et al. 2000). Seven genes involved in phage lysis were selected, including two endolysins (glycosidase and transglycosilase), three holins (class 1, class 2, and class 3), one lysozyme and one lysis protein $\mathrm{B}$.

\section{Overall description of GeoChip 4 features}

Instead of the spotted array platform used for GeoChip 3.0 (round spots; $100-150 \mu \mathrm{m}$ in diameter), an in situ synthesized microarray platform is employed for GeoChip 4 , resulting in much smaller square spots (13 $\mu \mathrm{m} \times 13 \mu \mathrm{m}$, about $1 / 46$ to $1 / 105$ of the spot size in spotted arrays). GeoChip 4 is a more compact and dense array $(8.9 \mathrm{~mm} \times 6.5 \mathrm{~mm})$ with $\sim 135 \mathrm{~K}$ probes per array and 12 arrays on each slide, making GeoChip 4 a highdensity functional gene array able to hybridize multiple samples on a single slide under nearly identical conditions. In total, 82074 probes targeting 410 functional gene families were included in GeoChip 4, covering 141995 coding sequences (CDS) (Table 1). Among these, $18098(22.1 \%)$ are sequence-specific probes and 63976 $(78.0 \%)$ are group-specific probes (Table 2). Specifically, 21541 probes $(26.3 \%)$ targeted 45 microbial stress response genes, 17056 probes (20.8\%) targeted 184 organic remediation genes, and 11034 probes (13.4\%) targeted 41 genes involved in carbon cycling processes. At the taxonomic level, 73106 probes (89.1\%) targeted 4332 bacterial strains, $2555(3.1 \%)$ for 188 archaeal strains, $4965(6.1 \%)$ for 420 eukaryotic strains, 1071 (1.3\%) for 273 bacteriophage, and the remaining for uncultured/unidentified/environmental organisms (Table 3). In addition, GeoChip 4 also contains 640 (80 replicates $\times 8$ degenerate probes) probes targeting 165 rRNA sequences as positive controls, 1689 (3 replicates $\times 563$ probes) probes targeting seven sequenced hyperthermophile genomes as negative controls. Moreover, 6000 identical probes were included as a common oligonucleotide reference standard (CORS) for data normalization and comparison (Liang et al. 2010). 
Table 1 Comparisons of major differences between GeoChip 3.0 and GeoChip 4

\begin{tabular}{|c|c|c|}
\hline & GeoChip 3.0 & GeoChip 4 \\
\hline $\begin{array}{l}\text { Fabrication } \\
\text { method }\end{array}$ & Spotted array & $\begin{array}{l}\text { In situ } \\
\text { synthesized array }\end{array}$ \\
\hline $\begin{array}{l}\text { Feature shape } \\
\text { and size }\end{array}$ & $\begin{array}{l}\text { Circle, } 100-150 \mu \mathrm{m} \\
\text { in diameter }\end{array}$ & $\begin{array}{l}\text { Square, } 13 \mu \mathrm{m} \\
\quad \times 13 \mu \mathrm{m}\end{array}$ \\
\hline Array size & $25 \mathrm{~mm} \times 76 \mathrm{~mm}$ & $8.9 \mathrm{~mm} \times 6.5 \mathrm{~mm}$ \\
\hline Capacity per slide & $\begin{array}{l}1 \text { array } x \\
\quad 30000 \text { probes }\end{array}$ & $\begin{array}{l}12 \text { arrays } \times \\
135000 \text { probes }\end{array}$ \\
\hline $\begin{array}{l}\text { Number of } \\
\text { gene families }\end{array}$ & 292 & 410 \\
\hline Number of probes & 27812 & 82074 \\
\hline $\begin{array}{l}\text { Number of } \\
\text { covered CDS }\end{array}$ & 56990 & 141995 \\
\hline $\begin{array}{l}\text { Number of } \\
\text { covered strains }\end{array}$ & 3172 & 5247 \\
\hline $\begin{array}{r}\text { Minimum required } \\
\text { community DNA }\end{array}$ & $2 \mu \mathrm{g}$ & $0.5 \mu \mathrm{g}$ \\
\hline
\end{tabular}

Specificity for positive and negative control probes as well as CORS was also verified by searching against NCBI nt database.

\section{Computational evaluation of designed probes}

Specificity for GeoChip 4 probes was computationally evaluated against the NCBI database based on sequence identity, continuous stretch length and free energy. For sequence-specific probes, the maximum identity, maximum stretch length and minimal free energy to their closest nontarget sequences were calculated. About $66.5 \%$ of probes showed maximum sequence identities of $60 \%$ or less to their nontargets. Only $4.2 \%$ of probes showed $86-90 \%$ sequence identity (Fig. 1a), 6.4\% had 19 20 base continuous stretch (Fig. 1b), and 6.8\% had -35 to $-25 \mathrm{kcal} / \mathrm{mol}$ free energy to their nontargets (Fig. 1c). For group-specific probes, the minimum identity, minimum stretch length and maximum free energy to its group members were calculated. Approximately $92 \%$ of group-specific probes were identical to their group members (Fig. 1d,e), and more than $79 \%$ showed -85 to $-65 \mathrm{kcal} / \mathrm{mol}$ free energy to their group members (Fig. 1f). All these results were consistent with the probe design criteria (He et al. 2010a), showing the designed probes were highly specific to their targets.

\section{Determining the minimal DNA amount for array hybridization}

DNA extraction of many environmental samples is not always an easy process, thus determining the appropriate amount of community DNA is important for successful microarray-based analyses. An insufficient amount of DNA during microarray hybridization will lead to inadequate observation of hybridized probes/ genes, while excessive amounts of DNA will lead to signal intensity saturation of dominant functional genes, resulting in invalid observations for comparative analysis. To address the above questions, ten DNA concentrations (each with three replicates) ranging from 0.001 to $4 \mu \mathrm{g}$ were hybridized with GeoChip 4 at $42{ }^{\circ} \mathrm{C}$ with $40 \%$ formamide. Probes with SNR $\geq 2.0$ in at least two of three replicates were treated as positives. The number of positive probes at each DNA concentration and overlap between any two DNA concentrations were examined. More than 10000 and 17500 positive hybridization spots were obtained with $50 \mathrm{ng}$ and $100 \mathrm{ng}$ DNA concentrations, respectively. Consistent hybridizations were observed with DNA amounts $\geq 0.5 \mu \mathrm{g}$, and more than 20000 positive probes were detected for all DNA concentrations $\geq 0.5 \mu \mathrm{g}$ (Fig. 2a). Thus, for a good hybridization, a minimum of $0.5 \mu \mathrm{g}$ total community DNA is required for environmental samples, and $1 \mu \mathrm{g}$ or more DNA is recommended. Also high overlap percentages of positive probes $(\sim 70-95 \%)$ were observed between the different DNA concentrations used, suggesting stable hybridizations of GeoChip 4 across replicates.

In addition, the relationship between signal intensity and DNA amount was also examined. Overlapped positive probes among all samples with different DNA concentrations were used. The signal intensity of each probe was averaged across the three technical replicates. Logtransformed average signal intensities of all probes were compared with log-transformed DNA concentrations. A significant linear relationship $(r=0.925)$ was observed between the average signal intensity and DNA concentrations (Fig. 2b), indicating that GeoChip 4 hybridization is quantitative for environmental samples.

\section{Application of GeoChip 4 to analyse soil microbial communities under warming}

The response of soil microbial communities to long-term warming was studied using GeoChip 4 . Ten soil samples (five treatments and five controls) were collected in April 2008 from an experimental warming site located in Central Oklahoma $\left(34^{\circ} 59^{\prime} \mathrm{N}, 97^{\circ} 31^{\prime} \mathrm{W}\right)$, which has been subjected to a continuous warming treatment at $2{ }^{\circ} \mathrm{C}$ higher than atmospheric temperature since 1999 (Luo et al. 2001). In total, 30632 probes were detected in at least 2 of 10 samples, with 23 630-26 515 probes per sample. Both DCA and nonparametric multivariate statistical tests showed significantly different microbial community structures and compositions between warming and control samples (Fig. 3) with $P$-values varying from 0.028 to 0.059 (ANOSIM: $R=0.348, P=0.059$; adonis: $F=0.234$, 
Table 2 Summary of probe and covered coding sequence information of GeoChip 4 based on gene categories

\begin{tabular}{|c|c|c|c|c|c|}
\hline $\begin{array}{l}\text { Gene } \\
\text { category }\end{array}$ & $\begin{array}{l}\text { No. genes or } \\
\text { enzymes }\end{array}$ & $\begin{array}{l}\text { No. } \\
\text { probes }\end{array}$ & $\begin{array}{l}\text { me No. sequence- } \\
\text { specific probes }\end{array}$ & $\begin{array}{l}\text { No. group- } \\
\text { specific probes }\end{array}$ & $\begin{array}{l}\text { No. covered } \\
\text { CDS }\end{array}$ \\
\hline Carbon cycling & 41 & 11034 & 3204 & 7830 & 18071 \\
\hline Acetogenesis & 1 & 122 & 35 & 87 & 250 \\
\hline Methane cycling & 3 & 498 & 244 & 254 & 1577 \\
\hline Carbon fixation & 4 & 1620 & 288 & 1332 & 3148 \\
\hline Carbon degradation & 33 & 8794 & 2637 & 6157 & 12996 \\
\hline Cellulose & 4 & 702 & 268 & 434 & 1246 \\
\hline Chitin & 3 & 1473 & 519 & 954 & 2295 \\
\hline Hemicellulose & 5 & 1380 & 363 & 1017 & 2026 \\
\hline Lignin & 4 & 934 & 569 & 365 & 1028 \\
\hline Pectin & 1 & 72 & 50 & 22 & 63 \\
\hline Starch & 8 & 2432 & 613 & 1819 & 3439 \\
\hline Others & 8 & 1801 & 255 & 1546 & 2899 \\
\hline Nitrogen cycling & 17 & 7386 & 3090 & 4296 & 10744 \\
\hline Ammonification & 2 & 969 & 210 & 759 & 1554 \\
\hline Anammox & 1 & 47 & 2 & 45 & 282 \\
\hline Assimilatory $\mathrm{N}$ reduction & 4 & 469 & 106 & 363 & 692 \\
\hline Dissimilatory $\mathrm{N}$ reduction & 2 & 646 & 193 & 453 & 1341 \\
\hline Nitrification & 2 & 1419 & 497 & 922 & 118 \\
\hline Denitrification & 5 & 2612 & 1318 & 1294 & 4534 \\
\hline Nitrogen fixation & 1 & 1224 & 764 & 460 & 2223 \\
\hline Phosphorus utilization & 3 & 1341 & 351 & 990 & 2261 \\
\hline Sulphur & 6 & 3113 & 1784 & 1329 & 4049 \\
\hline Adenylsulphate reductase & 3 & 563 & 301 & 262 & 549 \\
\hline Sulphite reductase & 2 & 2084 & 1336 & 748 & 2831 \\
\hline Sulphur oxidation & 1 & 466 & 147 & 319 & 669 \\
\hline Energy process & 4 & 853 & 436 & 417 & 1131 \\
\hline Cytochrome & 1 & 619 & 390 & 229 & 728 \\
\hline Hydrogenase & 2 & 197 & 40 & 157 & 348 \\
\hline P450 & 1 & 37 & 6 & 31 & 55 \\
\hline Metal resistance & 44 & 9272 & 1295 & 7977 & 17198 \\
\hline Aluminium & 1 & 162 & 30 & 132 & 270 \\
\hline Arsenic & 5 & 905 & 208 & 697 & 1551 \\
\hline Cadmium & 2 & 876 & 99 & 777 & 1284 \\
\hline Cadmium, cobalt, zinc & 3 & 1333 & 145 & 1188 & 2637 \\
\hline Chromium & 1 & 1067 & 129 & 938 & 1949 \\
\hline Cobalt & 1 & 62 & 8 & 54 & 118 \\
\hline Cobalt, nickel & 3 & 16 & 5 & 11 & 29 \\
\hline Copper & 5 & 1729 & 199 & 1530 & 3063 \\
\hline Lead & 3 & 69 & 13 & 56 & 119 \\
\hline Mercury & 7 & 733 & 169 & 564 & 1237 \\
\hline Nickel & 1 & 36 & 4 & 32 & 71 \\
\hline Selenium & 1 & 4 & 2 & 2 & 6 \\
\hline Silver & 4 & 402 & 45 & 357 & 934 \\
\hline Tellurium & 4 & 1290 & 136 & 1154 & 2542 \\
\hline Zinc & 2 & 555 & 99 & 456 & 1321 \\
\hline Miscellaneous & 1 & 33 & 4 & 29 & 67 \\
\hline Organic remediation & 184 & 17056 & 4692 & 12364 & 28716 \\
\hline Aromatics & 132 & 12831 & 3732 & 9099 & 21056 \\
\hline Aromatic carboxylic acid & 38 & 6068 & 1900 & 4168 & 9637 \\
\hline BTEX and related aromatics & 21 & 1131 & 225 & 906 & 2044 \\
\hline Chorinated aromatics & 11 & 717 & 205 & 512 & 1227 \\
\hline Heterocyclic aromatics & 9 & 154 & 68 & 86 & 234 \\
\hline Nitoaromatics & 11 & 981 & 187 & 794 & 1782 \\
\hline Polycyclic aromatics & 19 & 1138 & 375 & 763 & 1547 \\
\hline Other aromatics & 23 & 2642 & 772 & 1870 & 4585 \\
\hline
\end{tabular}


Table 2 (Continued)

\begin{tabular}{|c|c|c|c|c|c|}
\hline $\begin{array}{l}\text { Gene } \\
\text { category }\end{array}$ & $\begin{array}{l}\text { No. genes or } \\
\text { enzymes }\end{array}$ & $\begin{array}{l}\text { No. } \\
\text { probes }\end{array}$ & $\begin{array}{l}\text { me No. sequence- } \\
\text { specific probes }\end{array}$ & $\begin{array}{l}\text { No. group- } \\
\text { specific probes }\end{array}$ & $\begin{array}{l}\text { No. covered } \\
\text { CDS }\end{array}$ \\
\hline Chlorinated solvents & 6 & 600 & 161 & 439 & 1060 \\
\hline Herbicides related compounds & 13 & 1408 & 283 & 1125 & 2373 \\
\hline Pesticides related compounds & 5 & 492 & 96 & 396 & 928 \\
\hline Other hydrocarbons & 14 & 746 & 241 & 505 & 1368 \\
\hline Others & 14 & 979 & 179 & 800 & 1931 \\
\hline Antibiotic resistance & 11 & 3,334 & 589 & 2,745 & 5533 \\
\hline Transporters & 5 & 2316 & 294 & 2022 & 3979 \\
\hline$\beta$-lactamases & 4 & 665 & 220 & 445 & 964 \\
\hline Others & 2 & 353 & 75 & 278 & 590 \\
\hline Stress & 45 & 21541 & 1313 & 20228 & 40635 \\
\hline Cold shock & 4 & 70 & 0 & 70 & 134 \\
\hline Heat shock & 5 & 1655 & 215 & 1440 & 2616 \\
\hline Glucose limitation & 2 & 87 & 3 & 84 & 134 \\
\hline Nitrogen limitation & 3 & 1461 & 11 & 1450 & 3939 \\
\hline Osmotic stress & 4 & 457 & 41 & 416 & 997 \\
\hline Oxygen limitation & 7 & 994 & 121 & 873 & 2020 \\
\hline Oxygen stress & 7 & 4765 & 255 & 4510 & 10375 \\
\hline Phosphate limitation & 6 & 5484 & 185 & 5299 & 9083 \\
\hline Protein stress & 2 & 587 & 14 & 573 & 1316 \\
\hline Radiation stress & 1 & 1264 & 54 & 1210 & 2695 \\
\hline Sigma factors & 4 & 4717 & 414 & 4303 & 7326 \\
\hline Bacteria phage & 40 & 1071 & 195 & 876 & 1987 \\
\hline Replication & 25 & 666 & 113 & 553 & 1188 \\
\hline Lysis & 7 & 133 & 22 & 111 & 289 \\
\hline Structural & 6 & 230 & 42 & 188 & 452 \\
\hline Host recognition/structural & 2 & 42 & 18 & 24 & 58 \\
\hline Virulence & 13 & 3726 & 315 & 3411 & 7444 \\
\hline Other (gyrB, bchY) & 2 & 2347 & 834 & 1513 & 4226 \\
\hline Total & 410 & 82074 & 18098 & 63976 & 141995 \\
\hline
\end{tabular}

$P=0.036$; MRPP: $\delta=0.136, P=0.028$ ). Further analysis of genes involved in carbon degradation, nitrogen cycling and phosphorus cycling showed significantly increased abundances for most of these genes $(P<0.05$, Fig. S3-S5, Supporting information). In total, 13 of 27 detected genes involved in carbon degradation (five for starch degradation and three for hemi-cellulose/cellulose degradation) increased significantly (Fig. S3, Supporting information), 10 of 16 detected nitrogen cycling genes increased significantly (Fig. S4, Supporting information), and 2 of 3 phosphorous cycling genes increased significantly (Fig. S5, Supporting information). These results suggested that warming could significantly stimulate microbially mediated nutrient cycling. Such observations were consistent with our previous results based on GeoChip 3.0 with soil samples collected in 2007 from the same site (Zhou et al. 2012).

As new features in GeoChip 4, gene families related to microbial stress responses (Fig. 4) and bacteriophages (Fig. S6, Supporting information) were also analysed. Specifically, the abundances of all four sigma factors, including $\sigma 70$ (primary sigma factor), $\sigma 24$ (extracytoplasmic/extreme heat stress), $\sigma 32$ (heat shock) and $\sigma 38$ (starvation/stationary phase), increased significantly ( $P$-value $\leq 0.05)$ in response to warming. The abundances of three genes involved in heat shock responses ( $\operatorname{naK}, \operatorname{grpE}$ and $h r c A$ ) also increased significantly, while genes related to cold shock responses remained unchanged. In accordance with the stimulated phosphorus cycling, genes related to phosphate limitation also increased significantly. Also, one gene (prov) involved in osmotic stress significantly increased in response to warming. Of 40 genes from bacteriophage, the majority showed no significant difference in response to warming. Only three genes, encoding endolysin transglycosylase, noncontractile major tail protein and scaffold protein, significantly increased in abundance under warming, and one gene for helicase P4 alpha type significantly decreased (Fig. S6, Supporting information), showing a minor effect of warming on bacteriophage in grassland soil. These results showed long-term warming significantly affected the microbial community functional structure and composition, by stimulating genes related to nutrient cycling and stress responses. 
Table 3 Summary of GeoChip 4 probes based on covered microbial domains and phylum information. Viruses were classified at the order/family level

\begin{tabular}{|c|c|c|c|c|c|}
\hline Domain & Phylum & $\begin{array}{l}\text { No. } \\
\text { genes }\end{array}$ & $\begin{array}{l}\text { No. } \\
\text { strains }\end{array}$ & $\begin{array}{l}\text { No. } \\
\text { probes }\end{array}$ & $\begin{array}{l}\text { No. covered } \\
\text { cds }\end{array}$ \\
\hline \multirow[t]{7}{*}{ Archaea } & & 118 & 173 & 2555 & 4390 \\
\hline & Euryarchaeota & 102 & 137 & 1518 & 2226 \\
\hline & Crenarchaeota & 63 & 31 & 732 & 1893 \\
\hline & Korarchaeota & 9 & 1 & 16 & 18 \\
\hline & Thaumarchaeota & 6 & 3 & 11 & 15 \\
\hline & Nanoarchaeota & 1 & 1 & 1 & 2 \\
\hline & Unclassified $^{*}$ & 14 & & 277 & 776 \\
\hline \multirow[t]{29}{*}{ Bacteria } & & 367 & 4138 & 73106 & 130347 \\
\hline & Proteobacteria & 346 & 2152 & 39141 & 71166 \\
\hline & Firmicutes & 210 & 822 & 10084 & 20585 \\
\hline & Actinobacteria & 251 & 490 & 6925 & 11785 \\
\hline & Bacteroidetes & 128 & 212 & 2768 & 4194 \\
\hline & Cyanobacteria & 120 & 142 & 2495 & 3671 \\
\hline & Chloroflexi & 89 & 26 & 995 & 1489 \\
\hline & Chlorobi & 52 & 20 & 652 & 844 \\
\hline & Verrucomicrobia & 82 & 11 & 623 & 683 \\
\hline & Spirochaetes & 60 & 42 & 241 & 592 \\
\hline & Planctomycetes & 88 & 18 & 510 & 563 \\
\hline & Deinococcus-Thermus & 77 & 14 & 344 & 540 \\
\hline & Thermotogae & 41 & 18 & 290 & 516 \\
\hline & Tenericutes & 33 & 74 & 207 & 457 \\
\hline & Acidobacteria & 71 & 5 & 300 & 393 \\
\hline & Chlamydiae & 26 & 21 & 128 & 341 \\
\hline & Aquificae & 44 & 22 & 198 & 290 \\
\hline & Fusobacteria & 36 & 21 & 138 & 228 \\
\hline & Lentisphaerae & 26 & 2 & 77 & 98 \\
\hline & Nitrospirae & 38 & 7 & 71 & 93 \\
\hline & Synergistetes & 20 & 4 & 77 & 84 \\
\hline & Dictyoglomi & 23 & 3 & 45 & 79 \\
\hline & Gemmatimonadetes & 22 & 1 & 57 & 64 \\
\hline & Elusimicrobia & 14 & 2 & 34 & 43 \\
\hline & Fibrobacteres & 17 & 1 & 39 & 41 \\
\hline & Deferribacteres & 15 & 1 & 30 & 34 \\
\hline & Thermodesulphobacteria & 5 & 6 & 19 & 15 \\
\hline & Candidatus Poribacteria & 1 & 1 & 4 & 3 \\
\hline & Unclassified $^{*}$ & 128 & & 6614 & 11456 \\
\hline \multirow[t]{17}{*}{ Eukaryota } & & 127 & 404 & 4965 & 4824 \\
\hline & Ascomycota & 112 & 227 & 3753 & 3517 \\
\hline & Basidiomycota & 48 & 125 & 841 & 839 \\
\hline & Streptophyta & 14 & 10 & 49 & 49 \\
\hline & Chordata & 5 & 8 & 18 & 16 \\
\hline & Echinodermata & 2 & 1 & 16 & 16 \\
\hline & Apicomplexa & 2 & 8 & 12 & 15 \\
\hline & Arthropoda & 4 & 7 & 20 & 13 \\
\hline & Neocallimastigomycota & 7 & 5 & 13 & 11 \\
\hline & Bacillariophyta & 3 & 2 & 11 & 10 \\
\hline & Microsporidia & 4 & 3 & 5 & 6 \\
\hline & Nematoda & 4 & 3 & 8 & 5 \\
\hline & Platyhelminthes & 1 & 1 & 4 & 5 \\
\hline & Chlorophyta & 1 & 2 & 5 & 3 \\
\hline & Glomeromycota & 3 & 1 & 4 & 3 \\
\hline & Phaeophyceae & 1 & 1 & 2 & 1 \\
\hline & Unclassified $^{*}$ & 13 & & 204 & 315 \\
\hline Viruses & (Order/Family) & 40 & 252 & 1071 & 1997 \\
\hline
\end{tabular}


Table 3 (Continued)

\begin{tabular}{|c|c|c|c|c|c|}
\hline Domain & Phylum & $\begin{array}{l}\text { No. } \\
\text { genes }\end{array}$ & $\begin{array}{l}\text { No. } \\
\text { strains }\end{array}$ & $\begin{array}{l}\text { No. } \\
\text { probes }\end{array}$ & $\begin{array}{l}\text { No. covered } \\
\text { cds }\end{array}$ \\
\hline & Caudovirales & 39 & 216 & 954 & 1687 \\
\hline & Leviviridae & 2 & 16 & 55 & 179 \\
\hline & Microviridae & 2 & 14 & 19 & 63 \\
\hline & Tectiviridae & 3 & 5 & 7 & 18 \\
\hline & Corticoviridae & 1 & 1 & 1 & 1 \\
\hline & Unclassified $^{*}$ & 12 & & 35 & 49 \\
\hline Others $^{\dagger}$ & & 29 & & 377 & 833 \\
\hline Total & & 410 & 4967 & 82074 & 141995 \\
\hline
\end{tabular}

*Unclassified refer to sequences that can only be identified at domain level, but not at phylum level or lower. Investigation of these sequences showed they are mostly from environmental samples.

$\dagger$ Others refer to sequences from some plasmids and uncultured/unidentified prokaryote organisms.

(a)
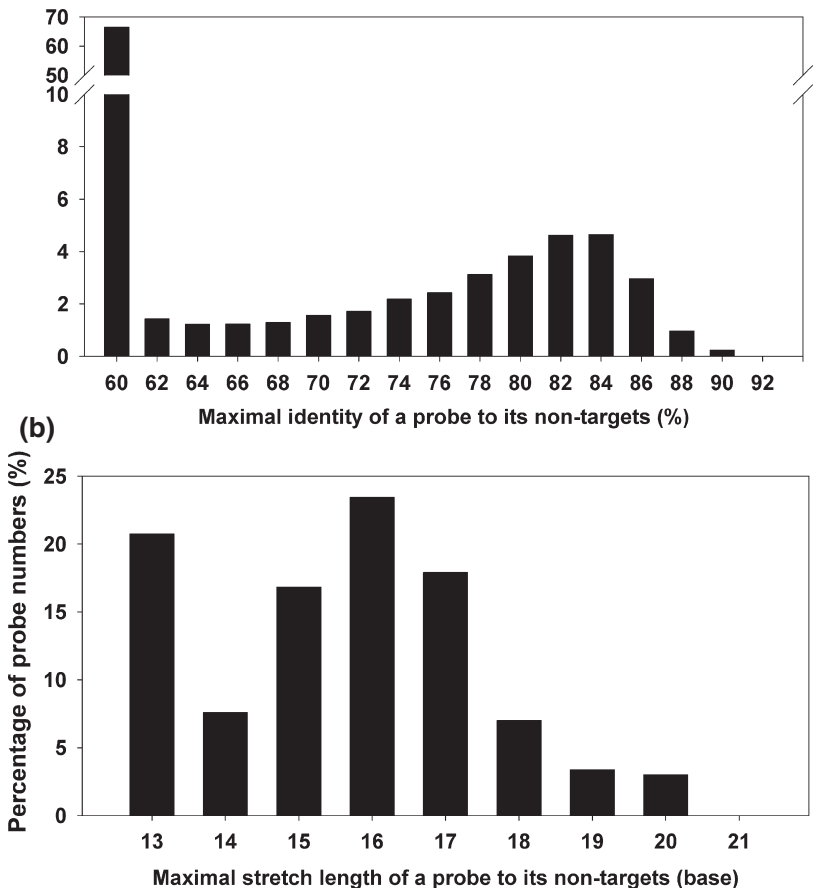

(c)

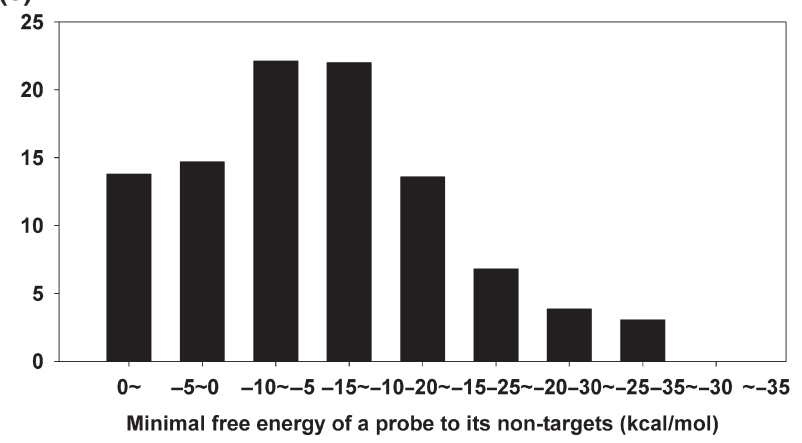

(d)

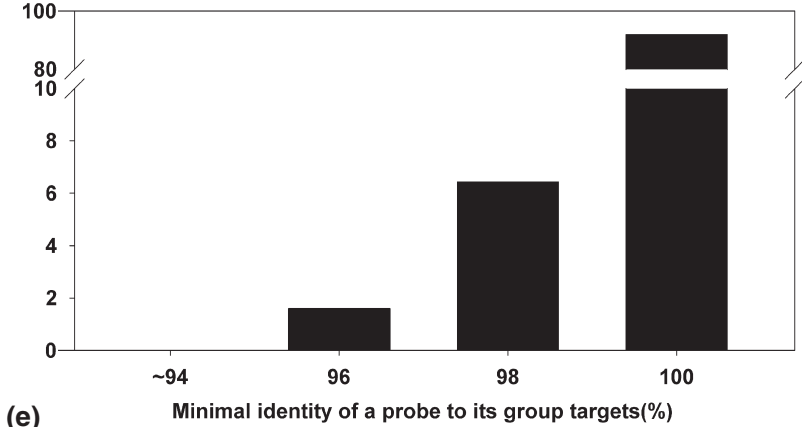

(e) Minimal identity of a probe to its group targets(\%)

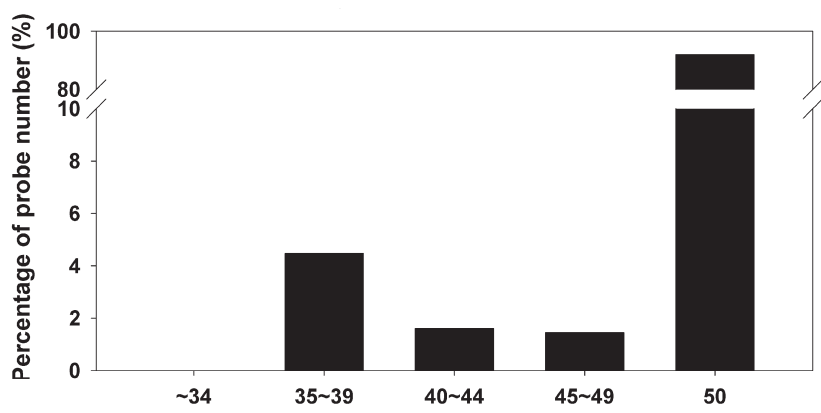

(f)

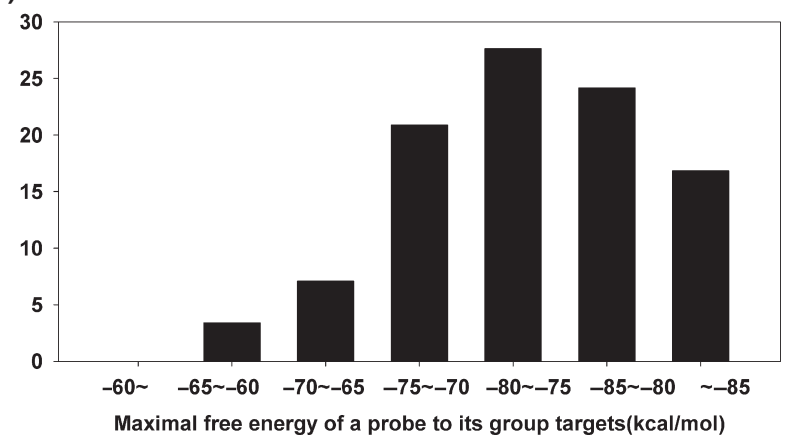

Fig. 1 Computational evaluation of sequence-specific probes at (a) maximal sequence identities, (b) maximal stretch length and (c) minimal free energy with their closest nontarget sequences; and group-specific probes at (d) minimal sequence identities, (e) minimal stretch length and (f) maximal free energy with their group targets. 


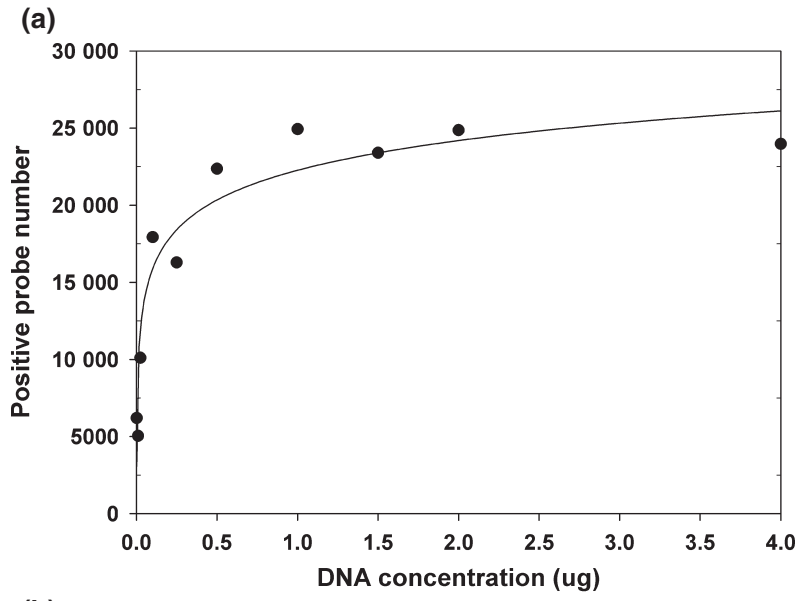

(b)

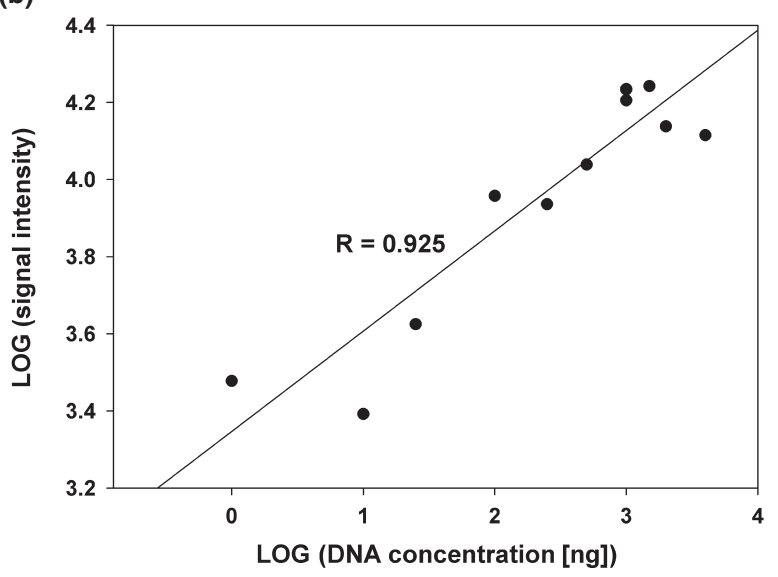

Fig. 2 Experimental assessment using environmental DNA extracted from one soil samples collected from the BioCON experimental sites with DNA amounts varying from 0.001 to $4 \mu$ g. (a) Number of positive probes detected when different amounts of DNA were used. Stable hybridization could be observed with DNA amount of more than $0.5 \mu \mathrm{g}$. (b) Correlation between Log (signal intensity) vs. log (DNA concentration). A high correlation coefficient value of 0.925 was observed. Three replicates were included for each DNA concentration. Probes showing up in at least two of three replicates were regarded as positive probes.

\section{Discussion}

Microarray-based metagenomic technology has been widely used for microbial community analysis, revolutionizing our understanding of microbial community structure, function and dynamics. Several different FGAs with differing purposes have been developed for microbial ecology studies (He et al. 2012a). These include GeoChip 2.0 and 3.0 for comprehensive microbial ecology studies (He et al. 2007, 2010a), the Hydrogenase Chip for characterizing hydrogen-producing and hydrogen-consuming microbes (Marshall et al. 2012) and a pmo $A$ functional gene array for methanotrophs (Bodrossy et al. 2003).

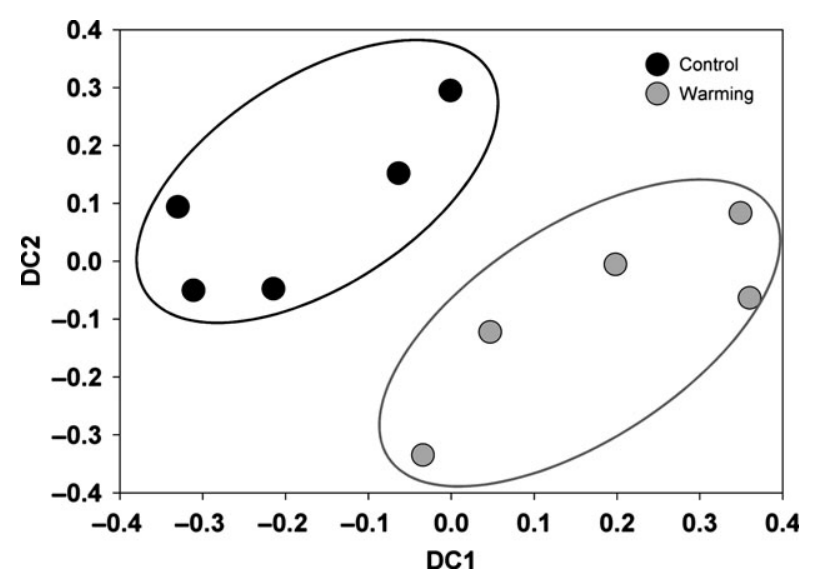

Fig. 3 Detrended correspondence analysis (DCA) of soil microbial communities using GeoChip 4 data of samples collected from long-term warming experimental site located in the Central Oklahoma. A total of 30632 probes detected in the whole community were analysed.

The developed GeoChip 4 here is much more comprehensive than any other FGAs currently available and has several new features. First, GeoChip has been continuously updated to reflect our most current knowledge of the gene families important to biogeochemistry, ecology and environmental science. Compared with previous versions, GeoChip 4 is more comprehensive, targeting 410 gene families with $\sim 82000$ probes covering $~ 142000$ CDS from more than 5200 microbial strains, including bacteria, archaea, fungi and viruses, enabling researchers to study more functional genes and microbial lineages within a single hybridization. Second, conventional gene families covered by previous GeoChips were manually checked and updated with twice as many CDS, making GeoChip 4 more comprehensive. Third, several important functional gene categories have been carefully selected and included, such as bacteriophage, microbial stress responses and virulence. In addition, GeoChip 4 has taken advantage of the in situ synthesized microarray format where probes are synthesized directly onto the surface of the glass slides, resulting in much smaller, more sensitive probe features. This also resulted in lower amounts of DNA, as low as 500 ng environmental DNA, being required for successful hybridizations, compared with previous versions of GeoChip that required a minimum of $2 \mu \mathrm{g}$ DNA for microarray hybridization. All these distinct features make GeoChip 4 a more sensitive, powerful and comprehensive metagenomic tool for analysing the functional diversity, composition, structure and dynamics of microbial communities, and linking their structure to environmental factors and ecosystem functioning.

Specificity is one of the most important issues in microarray technology, especially for environmental 


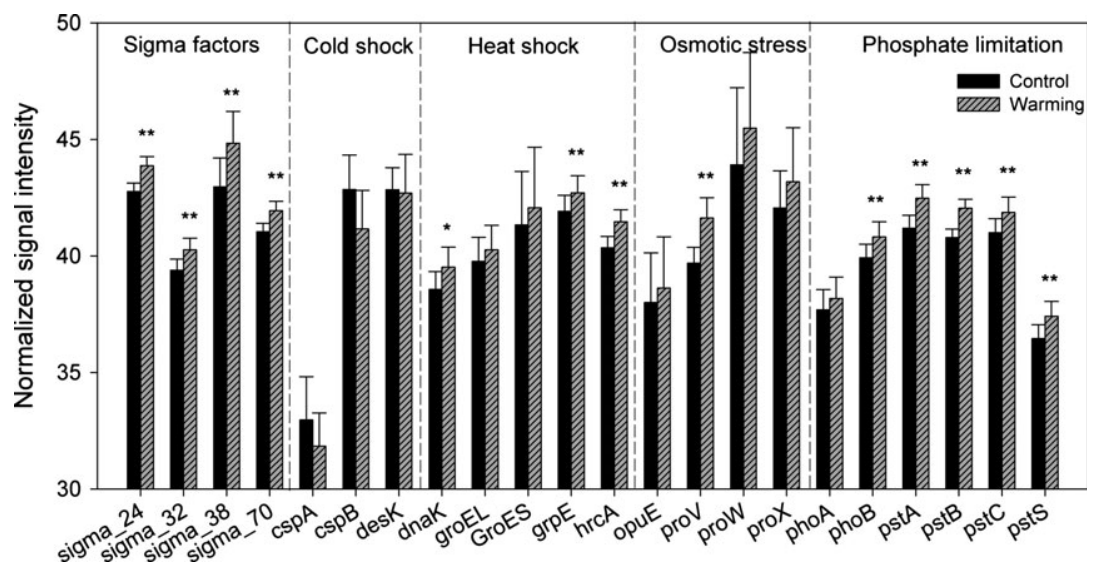

Fig. 4 The normalized average signal intensity of stress response genes related with cold/heat shock, osmotic stress, phosphate limitation and sigma factors under warming and the control. Signal intensities were the average abundances of detected genes under warming or control plots, normalized by the probe number of each gene. Error bars represent standard error. The differences between warming and control samples were tested by two-tailed paired $t$-tests. *: $P<0.10$; **: $P<0.05$.

samples with complex microbial communities. The specificity of GeoChip probes was guaranteed in multiple ways. First, the parameters used for designing the 50 -mer probes, both sequence specific and group specific, were experimentally evaluated and established (He et al. 2005; Liebich et al. 2006). Probes designed with those parameters were highly specific to their target sequences. Second, multiple criteria were considered simultaneously for high-quality probe selection by CommOligo 2.0, ensuring all designed probes were specific to all CDS in the input file and with similar thermodynamic properties ( $\mathrm{Li}$ et al. 2005). Third, all designed probes were checked against the most recent NCBI nt and env_nt databases for specificity, and nonspecific probes were discarded. Fourth, computational evaluation showed that only a very small portion of the designed probes $(5 \%)$ was very close to the criterion thresholds (He et al. 2005). Finally, extensive evaluations for functional gene probes designed with the same criteria were carried out in the laboratory during the past 15 years using pure culture DNA, mock community DNA and environmental samples, suggesting high specificity and sensitivity for these probes (Wu et al. 2001, 2006; Rhee et al. 2004; Tiquia et al. 2004; He et al. 2007, 2010a).

Application of GeoChip 4 to soil microbial communities sampled in 2008 from a long-term warming site showed consistent results with a previous study of samples collected in 2007 from the same site using GeoChip 3.0 (Zhou et al. 2012). Similar abundance patterns of functional genes involved in nutrient cycling processes such as carbon, nitrogen and phosphorous cycling processes were found in both studies, indicating GeoChip results were generally reproducible for similar samples collected from the same experimental site using different versions of the microarray, but with more information.
The results indicated several significant mechanisms by which microbial communities responded to climate warming. First, increased abundances of functional genes involved in carbon degradation suggested soil microbial communities play an important role of carbon cycling in response to long-term warming. Second, by increasing the abundance of genes involved in $\mathrm{N}$ and $\mathrm{P}$ cycling processes, nutrient cycling processes are enhanced and possibly promote plant nutrient use efficiency and plant growth. Third, long-term warming could be a stressor for soil microbial communities, which may adapt to such a stress by increasing the abundance of corresponding stress genes (e.g., sigma factor, heat shock, phosphate limitation genes). All these results indicate that microbial communities may play an important role in response to long-term warming and that the contribution of soil microbial communities should be considered in studying and predicting ecosystem feedbacks to climate warming.

In conclusion, a more comprehensive version of GeoChip 4 was developed in this study. Computational and experimental evaluations indicated GeoChip 4 to be a specific, sensitive and quantitative tool for microbial ecology studies. Application of GeoChip 4 to analyse soil microbial communities under long-term warming indicated warming significantly affected the functional composition and structure of soil microbial communities. To the best of our knowledge, GeoChip 4 is the most comprehensive functional gene array to study the functional diversity, composition, structure and dynamics of microbial communities, and to link their structure to environmental factors and ecosystem functioning. Further development of GeoChip will include more gene families for currently covered and uncovered biogeochemical processes, and new sequence variants from metagenome sequencing projects. 


\section{Acknowledgements}

This work was conducted by ENIGMA-Ecosystems and Networks Integrated with Genes and Molecular Assemblies (http://enigma.lbl.gov), a Scientific Focus Area Program at Lawrence Berkeley National Laboratory, was supported by the Office of Science, Office of Biological and Environmental Research (OBER), of the U.S. Department of Energy under Contract No. DE-AC02-05CH11231. This study was also supported by the OBER Biological Systems Research on the Role of Microbial Communities in Carbon Cycling Program (DE-SC0004601), by the U.S. National Science Foundation MacroSystems Biology programme under the contract (NSF EF1065844) and by Oklahoma Applied Research Support (OARS), Oklahoma Center for the Advancement of Science and Technology (OCAST) through the Projects AR062-034 and AR11-035, the State of Oklahoma.

\section{Conflict of interest}

None declared.

\section{References}

Ahn SJ, Costa J, Emanuel JR (1996) PicoGreen quantitation of DNA: effective evaluation of samples pre- or post-PCR. Nucleic Acids Research, 24, 2623-2625.

Ansorge WJ (2009) Next-generation DNA sequencing techniques. New Biotechnology, 25, 195-203.

Ashelford KE, Day MJ, Fry JC (2003) Elevated Abundance of Bacteriophage Infecting Bacteria in Soil. Applied and Environmental Microbiology, 69, 285-289.

Bardgett RD, Freeman C, Ostle NJ (2008) Microbial contributions to climate change through carbon cycle feedbacks. ISME Journal, 2, 805-814.

Bergh O, Borsheim KY, Bratbak G, Heldal M (1989) High abundance of viruses found in aquatic environments. Nature, 340, 467-468.

Bodrossy L, Stralis-Pavese N, Murrell JC et al. (2003) Development and validation of a diagnostic microbial microarray for methanotrophs. Environmental Microbiology, 5, 566-582.

Bossier P, Hofte M, Verstraete W (1988) Ecological significance of siderophores in soil. Advances in microbial ecology, 10, 385-414.

Brisson VL, West KA, Lee PK et al. (2012) Metagenomic analysis of a stable trichloroethene-degrading microbial community. ISME Journal, $\mathbf{6}$, 1702-1714.

Brodie EL, DeSantis TZ, Joyner DC et al. (2006) Application of a HighDensity Oligonucleotide Microarray Approach To Study Bacterial Population Dynamics during Uranium Reduction and Reoxidation. Applied and Environmental Microbiology, 72, 6288-6298.

Brodie EL, DeSantis TZ, Parker JPM et al. (2007) Urban aerosols harbor diverse and dynamic bacterial populations. Proceedings of the National Academy of Sciences, USA, 104, 299-304.

Carter MQ, Chen J, Lory S (2010) The Pseudomonas aeruginosa pathogenicity island PAPI-1 is transferred via a novel type IV pilus. Journal of Bacteriology, 192, 3249-3258.

Chen J, Novick RP (2009) Phage-mediated intergeneric transfer of toxin genes. Science, 323, 139-141.

Cossart P, Jonquières R (2000) Sortase, a universal target for therapeutic agents against Gram-positive bacteria? Proceedings of the National Academy of Sciences, USA, 97, 5013-5015.

Craig L, Taylor RK, Pique ME et al. (2003) Type IV pilin structure and assembly: X-ray and EM analyses of Vibrio cholerae toxin-coregulated pilus and Pseudomonas aeruginosa PAK pilin. Molecular Cell, 11, 1139-1150.
Deng $\mathrm{Y}, \mathrm{He} \mathrm{Z}, \mathrm{Xu} \mathrm{M}$ et al. (2012) Elevated carbon dioxide alters the structure of soil microbial communities. Applied and Environmental Microbiology, 78, 2991-2995.

Díez B, Bergman B, Pedrós-Alió C, Antó M, Snoeijs P (2012) High cyanobacterial nifH gene diversity in Arctic seawater and sea ice brine. Environmental Microbiology Reports, 4, 360-366.

Dong H, Nilsson L, Kurland CG (1995) Gratuitous overexpression of genes in Escherichia coli leads to growth inhibition and ribosome destruction. Journal of Bacteriology, 177, 1497-1504.

Eddy SR (1998) Profile hidden Markov models. Bioinformatics, 14, 755763.

Finlay BB, Falkow S (1997) Common themes in microbial pathogenicity revisited. Microbiology and Molecular Biology Reviews, 61, 136-169.

Fuangthong M, Herbig AF, Bsat N, Helmann JD (2002) Regulation of the Bacillus subtilis fur and perR genes by PerR: not all members of the PerR regulon are peroxide inducible. Journal of Bacteriology, 184, 32763286.

Galan JE, Collmer A (1999) Type III secretion machines: bacterial devices for protein delivery into host cells. Science, 284, 1322-1328.

Gans J, Wolinsky M, Dunbar J (2005) Computational improvements reveal great bacterial diversity and high metal toxicity in soil. Science, 309, 1387-1390.

Goff SA, Goldberg AL (1985) Production of abnormal proteins in E. coli stimulates transcription of ion and other heat shock genes. Cell, 41, 587-595.

Gomez P, Buckling A (2011) Bacteria-phage antagonistic coevolution in soil. Science, 332, 106-109.

Grath SM, Sinderen DV (2007) Bacteriophage: Genetics and Molecular Biology. Caister Academic Press, Norfolk, UK.

Gruber N, Galloway JN (2008) An Earth-system perspective of the global nitrogen cycle. Nature, 451, 293-296.

Hazen TC, Dubinsky EA, DeSantis TZ et al. (2010) Deep-Sea Oil Plume Enriches Indigenous Oil-Degrading Bacteria. Science, 330, 204-208.

He Z, Zhou J (2008) Empirical evaluation of a new method for calculating signal-to-noise ratio for microarray data analysis. Applied and Environment Microbiology, 74, 2957-2966.

He Z, Wu L, Li X, Fields MW, Zhou J (2005) Empirical Establishment of Oligonucleotide Probe Design Criteria. Applied and Environmental Microbiology, 71, 3753-3760.

He Z, Gentry TJ, Schadt CW et al. (2007) GeoChip: a comprehensive microarray for investigating biogeochemical, ecological and environmental processes. ISME Journal, 1, 67-77.

He Z, Deng Y, Van Nostrand JD et al. (2010a) GeoChip 3.0 as a highthroughput tool for analyzing microbial community composition, structure and functional activity. ISME Journal, 4, 1167-1179.

He Z, Xu M, Deng Y et al. (2010b) Metagenomic analysis reveals a marked divergence in the structure of belowground microbial communities at elevated CO2. Ecology Letters, 13, 564-575.

He Z, Deng Y, Zhou J (2012a) Development of functional gene microarrays for microbial community analysis. Current Opinion in Biotechnology, 23, 49-55.

He Z, Van Nostrand JD, Zhou J (2012b) Applications of functional gene microarrays for profiling microbial communities. Current Opinion in Biotechnology, 23, 460-466.

Hess M, Sczyrba A, Egan R et al. (2011) Metagenomic Discovery of Biomass-Degrading Genes and Genomes from Cow Rumen. Science, 331, 463-467.

Hoffmann-Berling H, Mazé R (1964) Release of male-specific bacteriophages from surviving host bacteria. Virology, 22, 305-313.

Huang WE, Zhou J (2012) When single cell technology meets omics, the new toolbox of analytical biotechnology is emerging. Current Opinion in Biotechnology, 23, 1.

Kallmeyer J, Pockalny R, Adhikari RR, Smith DC, D'Hondt S (2012) Global distribution of microbial abundance and biomass in subseafloor sediment. Proceedings of the National Academy of Sciences, USA, 109, 16213-16216. 
Kempf B, Bremer E (1998) Uptake and synthesis of compatible solutes as microbial stress responses to high-osmolality environments. Archives of Microbiology, 170, 319-330.

Kimes NE, Van Nostrand JD, Weil E, Zhou J, Morris PJ (2010) Microbial functional structure of Montastraea faveolata, an important Caribbean reef-building coral, differs between healthy and yellow-band diseased colonies. Environmental Microbiology, 12, 541-556.

Kline KA, Fälker S, Dahlberg S, Normark S, Henriques-Normark B (2009) Bacterial Adhesins in Host-Microbe Interactions. Cell Host \& Microbe, 5, 580-592.

Lasken RS (2007) Single-cell genomic sequencing using Multiple "Displacement Amplification. Current Opinion in Microbiology, 10, 510-516.

Leigh MB, Pellizari VH, Uhlik O et al. (2007) Biphenyl-utilizing bacteria and their functional genes in a pine root zone contaminated with polychlorinated biphenyls (PCBs). ISME Journal, 1, 134-148.

Li X, He Z, Zhou J (2005) Selection of optimal oligonucleotide probes for microarrays using multiple criteria, global alignment and parameter estimation. Nucleic Acids Research, 33, 6114-6123.

Liang Y, Li G, Van Nostrand JD et al. (2009) Microarray-based analysis of microbial functional diversity along an oil contamination gradient in oil field. FEMS Microbiology Ecology, 70, 324-333.

Liang Y, He Z, Wu L et al. (2010) Development of a Common Oligonucleotide Reference Standard for Microarray Data Normalization and Comparison across Different Microbial Communities. Applied and Environmental Microbiology, 76, 1088-1094.

Liang Y, Van Nostrand JD, Deng Y et al. (2011) Functional gene diversity of soil microbial communities from five oil-contaminated fields in China. ISME Journal, 5, 403-413.

Liebich J, Schadt CW, Chong SC et al. (2006) Improvement of Oligonucleotide Probe Design Criteria for Functional Gene Microarrays in Environmental Applications. Applied and Environmental Microbiology, 72, 1688-1691.

Liebich J, Wachtmeister T, Zhou J, Burauel P (2009) Degradation of Diffuse Pesticide Contaminants: Screening for Microbial Potential Using a Functional Gene Microarray. Vadose Zone Journal, 8, 703-710.

Liu W, Wang A, Cheng S et al. (2010) Geochip-Based Functional Gene Analysis of Anodophilic Communities in Microbial Electrolysis Cells under Different Operational Modes. Environmental Science \& Technology, 44, 7729-7735.

Liu W, Wang A, Sun D et al. (2012) Characterization of microbial communities during anode biofilm reformation in a two-chambered microbial electrolysis cell (MEC). Journal of Biotechnology, 157, 628-632.

Luo Y, Wan S, Hui D, Wallace LL (2001) Acclimatization of soil respiration to warming in a tall grass prairie. Nature, 413, 622-625.

Mackelprang R, Waldrop MP, DeAngelis KM et al. (2011) Metagenomic analysis of a permafrost microbial community reveals a rapid response to thaw. Nature, 480, 368-371.

MacLean D, Jones JDG, Studholme DJ (2009) Application of 'next-generation' sequencing technologies to microbial genetics. Nature Reviews Microbiology, 7, 287-296

Mardis ER (2008) The impact of next-generation sequencing technology on genetics. Trends in genetics, 24, 133.

Marshall IP, Berggren DR, Azizian MF et al. (2012) The Hydrogenase Chip: a tiling oligonucleotide DNA microarray technique for characterizing hydrogen-producing and -consuming microbes in microbial communities. ISME Journal, 6, 814-826.

Mason OU, Nakagawa T, Rosner M et al. (2010) First Investigation of the Microbiology of the Deepest Layer of Ocean Crust. PLoS ONE, 5, e15399.

Mazmanian SK, Ton-That H, Schneewind O (2001) Sortase-catalysed anchoring of surface proteins to the cell wall of Staphylococcus aureus. Molecular Microbiology, 40, 1049-1057.

Metzker ML (2010) Sequencing technologies [mdash] the next generation. Nature Reviews Genetics, 11, 31-46.

Neilands JB (1995) Siderophores: Structure and Function of Microbial Iron Transport Compounds. Journal of Biological Chemistry, 270, 2672326726 .
Pomposiello PJ, Demple B (2001) Redox-operated genetic switches: the SoxR and OxyR transcription factors. Trends in Biotechnology, 19, 109114.

Prescott LM (1993) Microbiology. William C Brown Pub, Boston, MA.

Qin J, Li R, Raes J et al. (2010) A human gut microbial gene catalogue established by metagenomic sequencing. Nature, 464, 59-65.

Qin J, Li Y, Cai Z et al. (2012) A metagenome-wide association study of gut microbiota in type 2 diabetes. Nature, 490, 55-60.

Rappe MS, Giovannoni SJ (2003) The uncultured microbial majority. Annual Review of Microbiology, 57, 369-394.

Reich PB, Knops J, Tilman D et al. (2001) Plant diversity enhances ecosystem responses to elevated $\mathrm{CO} 2$ and nitrogen deposition. Nature, 410, 809-810.

Rhee SK, Liu X, Wu L et al. (2004) Detection of genes involved in biodegradation and biotransformation in microbial communities by using 50mer oligonucleotide microarrays. Applied and Environment Microbiology, 70, 4303-4317.

Riede I, Drexler K, Eschbach M-L, Henning U (1987) DNA sequence of genes 38 encoding a receptor-recognizing protein of bacteriophages $\mathrm{T} 2, \mathrm{~K} 3$ and of K3 host range mutants. Journal of Molecular Biology, 194, 31-39.

Roesch LFW, Fulthorpe RR, Riva A et al. (2007) Pyrosequencing enumerates and contrasts soil microbial diversity. ISME Journal, 1, 283-290.

Schatz MC, Phillippy AM, Gajer P et al. (2010) Integrated microbial survey analysis of prokaryotic communities for the PhyloChip microarray. Applied and Environmental Microbiology, 76, 5636-5638.

Schloss PD, Handelsman J (2006) Toward a census of bacteria in soil. PLoS Computational Biology, 2, 5.

Shendure J, Ji H (2008) Next-generation DNA sequencing. Nature Biotechnology, 26, 1135-1145.

Singh A, Wyant T, Anaya-Bergman C et al. (2011) The capsule of Porphyromonas gingivalis leads to a reduction in the host inflammatory response, evasion of phagocytosis, and increase in virulence. Infection and Immunity, 79, 4533-4542.

Sintes E, Bergauer K, De CD, Yokokawa T, Herndl GJ (2013) Archaeal amoA gene diversity points to distinct biogeography of ammonia-oxidizing Crenarchaeota in the ocean. Environmental Microbiology, 15, $1647-1658$.

Sogin ML, Morrison HG, Huber JA et al. (2006) Microbial diversity in the deep sea and the underexplored "rare biosphere". Proceedings of the National Academy of Sciences, USA, 103, 12115-12120.

Suttle CA (1994) The Significance of Viruses to Mortality in Aquatic Microbial Communities. Microbial Ecology, 28, 237-243.

Suttle CA (2007) Marine viruses-major players in the global ecosystem. Nature Reviews Microbiology, 5, 801-812.

Taş N, van Eekert MHA, Schraa G et al. (2009) Tracking Functional Guilds: "Dehalococcoides" spp. in European River Basins Contaminated with Hexachlorobenzene. Applied and Environmental Microbiology, 75, 4696-4704.

Taylor LH, Latham SM, Woolhouse ME (2001) Risk factors for human disease emergence. Philosophical Transactions of the Royal Society of London. Series B, Biological sciences, 356, 983-989.

Thomassen E, Gielen G, Schutz M et al. (2003) The structure of the receptor-binding domain of the bacteriophage T4 short tail fibre reveals a knitted trimeric metal-binding fold. Journal of Molecular Biology, 331, 361-373.

Tiquia SM, Wu L, Chong SC et al. (2004) Evaluation of 50-mer oligonucleotide arrays for detecting microbial populations in environmental samples. BioTechniques, 36, 664-670.

Tobias J, Svennerholm AM (2012) Strategies to overexpress enterotoxigenic Escherichia coli (ETEC) colonization factors for the construction of oral whole-cell inactivated ETEC vaccine candidates. Applied Microbiology and Biotechnology, 93, 2291-2300.

Trivedi P, He Z, Van Nostrand JD et al. (2012) Huanglongbing alters the structure and functional diversity of microbial communities associated with citrus rhizosphere. ISME Journal, 6, 363-383.

Van Nostrand JD, Wu W-M, Wu L et al. (2009) GeoChip-based analysis of functional microbial communities during the reoxidation of a 
bioreduced uranium-contaminated aquifer. Environmental Microbiology, 11, 2611-2626.

Walker A, Parkhill J (2008) Single-cell genomics. Nature Reviews Microbiology, 6, 176-177.

Wang F, Zhou H, Meng J et al. (2009) GeoChip-based analysis of metabolic diversity of microbial communities at the Juan de Fuca Ridge hydrothermal vent. Proceedings of the National Academy of Sciences, USA, 106, 4840-4845.

Weigel C, Seitz H (2006) Bacteriophage replication modules. FEMS Microbiology Reviews, 30, 321-381.

Weinbauer MG (2004) Ecology of prokaryotic viruses. FEMS Microbiology Reviews, 28, 127-181.

Whitman WB, Coleman DC, Wiebe WJ (1998) Prokaryotes: The unseen majority. Proceedings of the National Academy of Sciences, USA, 95, 65786583.

Wommack KE, Colwell RR (2000) Virioplankton: viruses in aquatic ecosystems. Microbiology and Molecular Biology Reviews, 64, 69-114.

Woolhouse ME, Gowtage-Sequeria S (2005) Host range and emerging and reemerging pathogens. Emerging Infectious Diseases, 11, 18421847.

Woyke T, Tighe D, Mavromatis Ket al. (2010) One bacterial cell, one complete genome. PLoS ONE, 5, e10314.

Wu L, Thompson DK, Li G et al. (2001) Development and Evaluation of Functional Gene Arrays for Detection of Selected Genes in the Environment. Applied and Environmental Microbiology, 67, 5780-5790.

Wu L, Liu X, Schadt CW, Zhou J (2006) Microarray-Based Analysis of Subnanogram Quantities of Microbial Community DNAs by Using Whole-Community Genome Amplification. Applied and Environmental Microbiology, 72, 4931-4941.

Wu HJ, Wang AH, Jennings MP (2008) Discovery of virulence factors of pathogenic bacteria. Current Opinion in Chemical Biology, 12, 93 101

Xiong J, Wu L, Tu S et al. (2010) Microbial Communities and Functional Genes Associated with Soil Arsenic Contamination and the Rhizosphere of the Arsenic-Hyperaccumulating Plant Pteris vittata L. Applied and Environmental Microbiology, 76, 7277-7284.

Xu M, Wu W-M, Wu L et al. (2010) Responses of microbial community functional structures to pilot-scale uranium in situ bioremediation. ISME Journal, 4, 1060-1070.

Yang S, Bourne PE (2009) The evolutionary history of protein domains viewed by species phylogeny. PLoS ONE, 4, 0008378.

Yatsunenko T, Rey FE, Manary MJ et al. (2012) Human gut microbiome viewed across age and geography. Nature, 486, 222-227.

Yergeau E, Bokhorst S, Kang S et al. (2012) Shifts in soil microorganisms in response to warming are consistent across a range of Antarctic environments. ISME Journal, 6, 692-702.

Young I, Wang I, Roof WD (2000) Phages will out: strategies of host cell lysis. Trends in Microbiology, 8, 120-128.

Zhou J, Bruns MA, Tiedje JM (1996) DNA recovery from soils of diverse composition. Applied and Environmental Microbiology, 62, 316-322.

Zhou J, Kang S, Schadt CW, Garten CT (2008) Spatial scaling of functional gene diversity across various microbial taxa. Proceedings of the National Academy of Sciences, USA, 105, 7768-7773.
Zhou J, Xue K, Xie J et al. (2012) Microbial mediation of carbon-cycle feedbacks to climate warming. Nature Climate Change, 2, 106-110.

Zhou J, Liu W, Deng Y et al. (2013) Stochastic Assembly Leads to Alternative Communities with Distinct Functions in a Bioreactor Microbial Community. mBio, 4, e00584-e00612.

Q.T., Z.H., J.V.N. and J.Z. wrote the manuscript. H.Y., K.X., L.W., and T.Y. designed and performed microarray experiments. Q.T., H.Y. and K.X. processed and analysed the microarray data. Q.T., Y.D., Y.Q. and Z.S. built the GeoChip probe design pipeline. A.Z., J.V., Y.L. and CH contributed to keywords generation for newly added gene families. A.W. and J.Z. oversaw the whole study. All authors read and approved the final manuscript.

\section{Data Accessibility}

Normalized GeoChip 4 data for the long-term warming effects on soil microbial communities study at a Central Oklahoma site are available at http://ieg.ou.edu/ 4download. Details for the all covered gene families in GeoChip 4 are also available at the above website.

\section{Supporting Information}

Additional Supporting Information may be found in the online version of this article:

Figure S1 Flowchart of GeoChip 4.0 design pipeline.

Figure S2 Illustration of the layout of GeoChip 4.0 probes.

Figure S3 The normalized average signal intensity of genes involved in carbon degradation process under warming and the control conditions.

Figure S4 The normalized average signal intensity of genes involved in nitrogen cycling process under warming and the control.

Figure S5 The normalized average signal intensity of genes involved in phosphorus cycling process under warming and the control.

Figure S6 The normalized average signal intensity of genes related with bacteriophage under warming and the control. 